\title{
Doris Arnold: the Making of a Radio Star, 1926-1939
}

\section{Abstract}

Doris Arnold (1904-1967) was a highly popular BBC radio personality. She was especially feted for her gramophone record programme These you have Loved which she produced at the BBC (British Broadcasting Corporation) and presented from 1938, making her the UK's first female 'Disc Jockey'. Despite her fame at the time, however, Arnold is oddly absent from broadcasting histories and little is known about today. Hers was one of the best known 'rags to riches' narratives of the early BBC: a young woman who started as a typist but whose musical talent propelled her to stardom. This article explores Arnold's rise to fame in the 1920s and 1930s. It does this through a detailed evaluation of her personal staff files, using these as a vehicle to demonstrate the ways in which documents such as these can add to our understanding of women who worked at the BBC in its early days. A close reading of the files exposes a complexity of gendered issues including status, pay and clothing.

On 18 December 1935, the Director of the BBC's Variety Department, Eric Maschwitz, jotted down a recommendation in connection with one of his staff, Doris Arnold (1904-1967). ${ }^{1}$ Her 'Ten Year Bonus' was due, a reward he strongly endorsed. ' 'A very clever worker', he noted, 'and one of the most remarkable in the $\mathrm{BBC}^{\prime}$. Maschwitz's glowing words would not have come as a surprise to the BBC's listening public. Comments in Radio Pictorial between 1935 and 1937 include 'Doris Arnold is an extraordinary girl', '... one of the finest pianists in the business', '... one of the most popular BBC personalities' , '... the latest recruit to the gay company of Variety Producers'. ${ }^{3}$ As these accolades attest, by the mid-1930s, Doris Arnold was a national star. Her remarkable rise, from typist to 'talent' was frequently retold in the press, and within the $\mathrm{BBC}$ she was held up as an example of how even the lowliest employee could rise through the ranks. Yet, since the heady days of her success, Arnold has received hardly any attention in either histories of the BBC or histories of women's broadcasting, which is particularly surprising as she can be claimed as the UK's first female 'Disc Jockey'. 
Because of its longevity and status, the BBC is one of the most extensively researched broadcasting organisations in the world, but this has tended to be in terms of institutional politics and programmes, with a focus on men. Asa Briggs' five volume history of the BBC (published between 1961 and 1995) is testimony to this approach. It is only in recent years that the role played by women has gradually been uncovered, as will be expanded on below. This article seeks to broaden our knowledge of Arnold's early BBC career, while suggesting ways in which 'hidden histories' of women in broadcasting can be told. It focuses on her staff files to show how careful unpicking of institutional and administrative documents can reveal unexpected aspects of an individual's personal life alongside wider employment issues. All scholarship builds upon the work of others and this article is indebted to the work of David Hendy, Alec Badenoch and Kristin Skoog, and their reflections on biography and media history. Hendy highlights the important part played by biography and emotion within broadcasting history, something that has tended to be overlooked, and argues that it is only by engaging with a deeper understanding of the individual that a fuller picture can emerge. ${ }^{4}$ Badenoch and Skoog argue that, because women in broadcasting are more likely than men to have separate, entangled existences that go beyond the media itself, is therefore vital to take a multifaceted approach to studying and writing these histories. ${ }^{5}$ Certainly, in the case of Doris Arnold, it is not just her BBC work that is revealed through an analysis of her staff files.

The period under scrutiny here, 1928-1939, is only a slice of Arnold's successful career, but it was the time that she became established at the BBC (she would leave in 1952). She joined the BBC in 1926, aged twenty one, already experienced in clerical work. Her first job was as a shorthand typist but famously she was 'spotted' as a talented pianist and, in 1928, was promoted to the role of musical accompanist. What began as the general accompanist duties such as providing the accompaniment to artistes, playing at auditions and performing in $\mathrm{BBC}$ concerts, grew into a complex and irreplaceable musical role that culminated in Arnold becoming the producer and 
compere of her own gramophone programme These you have Loved in 1938, which she would present for the next 25 years.

\section{Locating Doris Arnold}

Although 'The Women who Oil Radio's Wheels' were widely acknowledged at the time, the women who worked at the BBC prior to 1939 then largely slipped from view. ${ }^{6}$ It was not until the mid-1990s that their presence began to receive scholarly attention with a number of biographical articles and books: Fred Hunter and Michael Carney on the Talks Director Hilda Matheson and Delia JarrettMacauley on the first black woman producer, Una Marson. ${ }^{7}$ In 2009, Michael Bailey was the first to explore women's programming on the BBC in the $1920 \mathrm{~s}$ and $1930 \mathrm{~s} .^{8}$ This subject was extensively expanded upon by Maggie Andrews in her 2012 book, Domesticating the Airwaves: Broadcasting, Domesticity and Femininity. ${ }^{9}$ My own monograph, Behind the Wireless: A History of Early Women in the $B B C$, was published in $2016 .{ }^{10}$

Recent biographical scholarship reveals a number of different approaches to the recovery of pioneering BBC women. For instance, for her discussion on Hilda Matheson and Olive Shapley, both significant interwar figures at the BBC, Virginia Marsden looked to contemporary writings and autobiography amongst her source material. ${ }^{11}$ Mary Adams' 1930s work as a science producer was revealed by Allan Jones through contributor files, programme notes and the memoirs of male colleagues. ${ }^{12}$ Jeannine Baker scrutinised contemporary news reports, personal papers and the BBC oral history collection for her portrayal of the Australian Muriel Howlett's time with the Corporation, which began in $1935 .{ }^{13}$ Jennifer Purcell, writing about the radio star Mabel Constanduros who came to prominence on the BBC from 1925, listed listening reports, obituaries and an unpublished manuscript within her bibliography. ${ }^{14}$ For this case study I use material from the popular journal Radio Pictorial, programme listings from Radio Times and a 1967 interview from the BBC radio programme Desert Island Discs as well as BBC staff files. ${ }^{15}$ 
Arnold is rare in being one of a handful of $\mathrm{BBC}$ women who merits a mention in Briggs who locates her in 1930, in the Vaudeville Section, describing how she became 'well-known to listeners everywhere with her programme (1938) These you have Loved. ${ }^{16}$ He also names her in 1933, working as a Musical Assistant to John Watt and Harry Pepper in the newly created Variety Department. Her colleague Jean Melville is also introduced, as an extra accompanist. ${ }^{17}$ (Watt, Pepper and Melville will all be returned to later.) Scannell and Cardiff, in their substantial social history of broadcasting in Britain in the 1920s and 1930s make no mention of Arnold in their two chapters on 'Variety'. ${ }^{18}$ Martin Dibbs, however, in his recent history of the BBC Variety Department, has recognised her significance. ${ }^{19}$

Arnold is one of a small number of $\mathrm{BBC}$ women for whom staff files have been retained. ${ }^{20}$ On the surface, these can appear to be dry affairs with their letters of appointment, records of sick leave and holiday pay. By their very nature, staff files are institutional; they are the repository of correspondence between the individual and their direct managers as well as the record of private discussions that wider management may have had about them. They are also selective. Yet careful reading of what is potentially sparse information can provide surprising insights, throwing light onto lifestyle and character. Particularly apparent are the sentiments of the time, evident in the language used and the writing style. The documents can also offer a candid perspective on the practices and culture of the BBC and the way that women staff were understood and treated.

Arnold's personal files are rich in the documents they contain, especially in terms of the female experience. Her records encompass the process of promotion and recognition, issues of salary and equal pay and a wealth of detail about her professional life, both inside and outside the BBC. In addition the files cover aspects of her personal life: her living arrangements, her health problems and the importance of fashionable clothes. There are also insights into male and female cultures at 
the BBC; in Arnold's case a social class background that set her apart from the predominantly university-educated men that she worked with. Striking is the emotion displayed within the documents; there is joy, frustration, anger, pride. Taken together, these pointers enable us to paint a more rounded portrait of what it was like to be a woman at the BBC, within the context of the times.

\section{Joining the $B B C$}

Arnold was born on 4 November 1904, in Wimbledon, where her father worked as a joiner and carpenter. ${ }^{21}$ From a young age she had piano lessons, but these stopped when she was around twelve because her father 'wasn't going to continue paying money he could ill-afford' ${ }^{22}$ She attended Tiffin Girls' School for six years 'roughly 1915-1921', but whether she reached School Certificate level at the age of 16 or 'Highers' is not known. ${ }^{23}$ Although her formal piano lessons might have been over, throughout her teenage years Arnold continued to play, gaining amateur, and later professional, work as an accompanist. ${ }^{24}$ Her family 'had no faith in the musical profession as a means of livelihood' and after school, Arnold was steered towards clerical work. ${ }^{25}$ Her first job was at the London County Council (LCC) in their Stores Department, where she worked for three years doing 'shorthand, typing, accounts etc. ${ }^{26}$ She then moved to the Peter Jones department store in Central London where she worked for 'about a year' as assistant to the Chief Pay Clerk. She joined the BBC as a shorthand typist in February 1926. ${ }^{27}$

The first two years of Arnold's BBC career are difficult to unpick, from the extant records. We know that she was first placed in the Stores Department and from there was moved to the Administrative Department, then the Accounts Department and finally the Music Department, all in the space of fourteen months. This mobility across departments was commonplace for female secretarial and clerical employees at the BBC, especially in their early months, as the Women's Staff Administrator decided where an individual's skills and strengths were best placed. ${ }^{28}$ Arnold's initial wage was $£ 2.5 \mathrm{~s}$, which rose over this period by $5 \mathrm{~s}$ increments to $£ 2.15 \mathrm{~s} .{ }^{29}$ Although by UK norms these would 
have been considered good earnings for a shorthand typist, by BBC standards they were modest for a woman of her age and experience. ${ }^{30}$

It is not clear whether the move to the Music Department was purely fortuitous or because Arnold's musical ability had become known. We do know that it was while she was working in this department as secretary to Stanford Robinson, the BBC's Chorus Master (as well as secretary to several other members of the BBC orchestra) that her piano-playing talent was formally identified. Arnold avers that she 'one day deputized for a pianist who failed to turn up and this, with other incidents of a similar kind, eventually led me to my present position' ${ }^{31}$ This understated description is in stark contrast to the mythology that grew up around her rise to fame, which was frequently trumpeted in the press. Radio Pictorial, for instance, in its 10 January 1936 issue, explained that:

Although a skilled pianist, Doris had no idea of playing for a living until one lunchtime she timidly offered to play for a sudden rehearsal. Then a pianist was suddenly wanted for the comedienne Mabel Constanduros' programme one night. Thus Doris got her chance. ${ }^{32}$

Radio Pictorial's 29 October 1937 issue told a different story:

History does not relate in which department she began at the BBC but her big chance came when she was transferred to the 'buying' section. Could any work be more humdrum? Then a happy chance led her to the mike. The girl whose place she was taking had moved on to the Children's Hour and one day the Uncles and Aunts were in a jam because the pianist had not turned up for auditions. Her friend remembered Doris Arnold's passion for the piano, and she gladly stepped up to take the accompanist's place. ${ }^{33}$

Perhaps the 'friend' was Jean Melville who, in the 25 June 1937 issue of the magazine claimed: 
I virtually created the job for Doris Arnold, the girl who has achieved so much fame ... At first Doris was a sort of general secretary and musical collaborator with John Ansell and Stanford Robinson... Then they had a piano installed in the office and as I was so busy on the programmes, they found that it was a great help to have Doris playing over some of the orchestral arrangements for them. My work was increasing, so they gave her an unofficial audition and in that way she actually came into the programme... ${ }^{34}$

As we shall see, the relationship between Arnold and Melville may have been one of strain, so this 'claim', as with the earlier versions of the rise to fame, needs to be accepted with caution.

What actually happened appears to have been this. In April 1928, two vacancies for full-time accompanists were due to be advertised. Before these posts were filled Arnold, at the request of Valentine Goldsmith, the head of Administration, was to be given a trial. Goldsmith, although having no 'definite reason for thinking she is suitable', wished that 'all steps be taken to enable a junior member of the staff to advance, if warranted on merit'. ${ }^{35}$ At a time when dead end jobs were commonplace in the UK workplace, especially in terms of gender and social class, the BBC took a meritocratic approach. This had important connotations for staff mobility, particularly for female employees. $^{36}$

Arnold's trial in the Production Department was a success. It was reported that:

She is very keen, excellent at site reading, at present rather nervous, but is gradually overcoming this, and we think that when she gains more confidence and practice she will turn out a very good accompanist. ${ }^{37}$ 
On 18 April her transfer was confirmed, resulting in a hefty wage rise of $£ 1$ a week. Within two years, by April 1930, Arnold had been promoted to the salaried (monthly paid) staff on $£ 280$ a year. This was significant. Not only did the salaried grades confer higher status but there were also enhanced conditions of service such as payment by cheque, separate cloakroom facilities and far higher annual increments - $£ 20$ per annum rise was the basic rate. ${ }^{38}$ As we shall see, Arnold's salary would become a point of tension but by April 1939 she was earning $£ 620$ a year, placing her amongst the highest paid women in the BBC. ${ }^{39}$

Arnold's promotion to the Productions Department came at a time of rapid change for what would become known as 'Variety' at the BBC. At first she was part of a small Production Section which was responsible for light entertainment and then in 1930 she was moved to a separate 'Revue' Section. ${ }^{40}$ Brought in to head this new section was 'young and energetic' John Watt, who had introduced revue-style shows in his previous post at BBC Belfast (these were programmes that showcased popular music). ${ }^{41}$ In 1932, a new recruit joined the section, Harry S Pepper. Pepper, who came from a show business family, already had an established career as a pianist and composer. ${ }^{42}$ Watt and Pepper would launch many successful new series including Songs from the Shows (Watt) and The Kentucky Minstrels (Pepper).

According to Radio Times, Arnold appeared as a pianist in at least seventy different musical shows and programmes during these early years (between February 1929 and April 1933), the majority of which would have been performed at least twice as recording technology was not yet widely available. ${ }^{43}$ Many of the listings link her name with that of Harry S Pepper. Through their association Arnold learnt syncopated piano (two pianists playing the same piece of music simultaneously on two pianos) and the two would become legendary for their dual playing. ${ }^{44}$ 
Arnold's burgeoning career drew the attention of her managers, particularly the work she did beyond her role as an accompanist. In September 1930, Val Gielgud, who was in charge of the Production Department, noted that Arnold's position had 'become that of an assistant rather than that of accompanist' ${ }^{45}$ This distinction was important. The term 'producer' was rarely used at the BBC prior to the mid-1930s rather those performing this role were entitled 'assistants', as was the case for both Watt and Pepper. Because of this raise in status, Gielgud recommended an immediate salary increase for Arnold, outside the usual wage round. ${ }^{46}$ This was supported by the Director of Programmes, Roger Eckersley, who described Arnold as a 'clever pianist and very helpful to those for whom she is working.' He believed her salary should be more comparable to that of Jean Melville and so backed this request for a rise. ${ }^{47}$ Also in agreement was Goldsmith, who supported her advancement as being in line with the "office boy to Director General" attitude that encourages staff'. ${ }^{48}$ It was Charles Carpendale, second-in-command at the BBC (after the Director General, John Reith) who gave final approval to a special pay rise for Arnold of $£ 20$.

The comparison with Jean Melville is noteworthy. Melville had been recruited to the BBC as an accompanist in October 1927 and like all those who made frequent appearances on the airwaves, she would become a significant radio personality. Melville's BBC career is considerably underresearched so to catch even a glimpse of her is instructive. However, she does not appear to have had the creative flair of Arnold; she never stepped away from piano playing into a producer role, as Arnold would do. In October 1930, Melville's salary was $\mathrm{f375}$ per annum, so considerably more than Arnold’s $£ 280$, and this was certainly a factor in the approval for an immediate rise for Arnold. Although Arnold's salary was increased, her status was not resolved. In the eyes of BBC administration, Arnold remained an accompanist. It was not until April 1933, and the creation of the new Variety Department that her status changed. 


\section{Arnold and the Variety Department}

The growing popularity of light entertainment led to the creation of a separate Variety Department in $1933 .{ }^{49}$ Under the newly appointed Director of Variety, Eric Maschwitz, were six 'producers' (all men) together with Doris Arnold, (Musical Assistant) and Jean Melville (Accompanist). ${ }^{50}$ For many in the new department little would change and Arnold continued to work alongside Watt and Pepper. Now close friends, the three shared an office and were affectionately known as 'The Gang'. ${ }^{51}$

So, what did Arnold do? Piecing together an individual's role at the BBC can be tricky. Prior to the mid-1930s, positions were rarely advertised so there are no job descriptions. In addition, the novel nature of broadcasting meant that similar roles outside of the Corporation were few, so comparisons are hard to make. Fortunately, Arnold described her work in the new department in some detail in a claim for a wage rise. In September 1933 she wrote to the Establishment Officer, Douglas Clarke, requesting the rise and in support attached a three-page document that demonstrated how her job had changed since she first started as an accompanist. ${ }^{52}$ Arnold identified seven different areas of work:

1) Accompanying at all auditions. (Auditions were the life-blood of the $B B C$, it was the way in which they discovered new talent. Having a talented pianist to support up-and-coming artistes was vital.) 2) Playing two pianos with Harry S Pepper. (This was her syncopated work. To underline her value to the BBC, she added a note that she had earned $f 25$ a week for two weeks doing this at the Plaza the previous Christmas, playing for just 75 minutes a day.)

3) Helping to find musical numbers for shows. (Arnold expanded on this aspect of her job, explaining how Watt/Pepper left her to decide how each chosen number should be worked. This could be, for example: the number of verses and choruses; whether the Revue Chorus was required; explaining to the orchestrator how these requirements could be achieved, 'in fact, generally taking over the musical lay-out of the show.') 
4) Overseeing, on her own, many productions of Songs from the Shows. ${ }^{53}$ (John Watt had introduced this popular evening strand in April 1931. With Watt constantly needing to write and prepare new revues he was, she believed, grateful that she was able to take this on.)

5) Doing all four-part chorus arrangements where these were included in any Watt/Pepper show. (With respect to The Kentucky Minstrels, she had done several arrangements for a twenty-six strong male chorus, which were 'specially commended in the Press'.)

6) Taking the first chorus rehearsals of any Watt/Pepper show.

7) Making visits to artistes on behalf of the BBC. (The example Arnold gave was Dorothy Dickson and Jessie Matthews, two major UK stars, in connection with their appearances on Songs from the Shows. Her role had been to find out what they wanted to sing, to tactfully combine this with the BBC's own ideas and then to ensure that the artistes were happy with the outcome.)

A subsequent memorandum in July 1935, from Mungo Dewar the Executive of the Variety Department, gives an even fuller impression of her role. ${ }^{54}$ As Arnold had done, Dewar used details of her extensive workload as evidence that she deserved a rise. Alongside a list of the programmes she had taken part in, from September 1934 to March 1935, were extensive comments. With regard to Songs from the Films (of which there were six performances alone in October 1934, three shows, performed twice each) Dewar noted, 'Chorus arrangements and playing in the rehearsals and both transmissions. Every one of these programmes entails at least 4 weeks work' ${ }^{55}$ For The Kentucky Minstrels, aired on 15 and 16 November, he emphasized how, 'This is one of the biggest shows which Miss Arnold has to tackle and it involves 26 male voice chorus arrangements which practically amounts to composing; then there is attendance at rehearsals etc.' Also in November 1934 there were two broadcasts of Charing Cross Road for which 'Miss Arnold did all the chorus arrangements for this show which involved at least 14 days work in preparation and actual arranging.' The Songs from the Films performances in early January 1935 had entailed 'a mapping out of an hour's continuous music, contrasting and balancing and working out in chronological order; arranging of 
band parts in detailed order'. Dewar was unequivocal that Arnold's achievements were 'outstanding in any one person'. Arnold was plainly a huge asset to the department, to which Maschwitz concurred. All BBC staff had an annual 'Confidential Report' written by their manager, which was linked to the April pay round. Maschwitz opened Arnold's 1936 report by stating:

I cannot write too highly of her work during the past year. Her chorus arrangements for such productions as Kentucky Minstrels and Songs from the Shows are absolutely first class and in the opinion of those qualified to judge she is now one of the very best chorus arrangers in the country. ${ }^{56}$

John Watt, who took over as Director of the Variety Department in 1937 (following the resignation of Maschwitz) also sang Arnold's praises. In 1937, Arnold had made her debut as a producer. The following year the two series she had originated, The Melody is There and These you have Loved, were acclaimed as 'highly successful' having received 'a phenomenal response from listeners, both in unsolicited requests and appreciations ${ }^{\prime}{ }^{57}$ To be the originator of even one new series was a considerable achievement. The Melody is There, billed in Radio Times as a 'popular song feature', ran for three series (October 1937-October 1939). ${ }^{58}$ Watt described Arnold as the 'producer and inaugurator' of the series which suggests that she was responsible for both the content and realisation each week. ${ }^{59}$ And there was praise from a Radio Times listener in November 1937:

Congratulations, I think, are due to Doris Arnold, the BBC's first woman producer in the Variety Department, for the wonderful way she has got on. Her half-hour of sweet music, under the title The Melody is There, on alternate Tuesdays is worth tuning on your radio for. $^{60}$ 
It was These you have Loved, however, Arnold's second individual project, that secured her fame. While 'live' performance remained at the heart of BBC programming, gramophone records were increasingly used and on 6 November 1938, Doris Arnold became the first woman to present such a series, one that she both curated and compered. Christopher Stone is credited as the UK's first 'Disc Jockey', his Gramophone Recitals was broadcast on the BBC from 1927-1934. While there were other gramophone programmes on the BBC, particularly by the mid-1930s, only occasionally were these hosted by a named presenter, usually it was an anonymous male announcer who introduced the discs. Despite the significance of These you have Loved, neither the programme file, nor Arnold's staff file, offer clear information about her role or how the series came about. ${ }^{61}$ She certainly 'heard countless records' while compiling each edition, which were a mix of light and classical music extracts. The development of the programme during the Second World War and into the 1950s (she presented the programme as a BBC staff member until 1952) is outside the scope of this article but unquestionably the series was an extraordinary success. ${ }^{62}$

\section{Behind the Public Face}

Arnold's staff files provide a range of material about her BBC work: the public face. But a wider picture can be uncovered through these files, one that divulges aspects of a private life. In Arnold's case, by analysing her claims for a salary increase and recognition of status, striking personal details are revealed. Scrutiny of these documents also offers a high level of detail about the character and motivation of a woman operating in a predominantly male environment.

Like many professional women in the 1930s, Arnold was reluctant to engage with negotiations about salary and status. ${ }^{63}$ Her first request for a pay rise and wider recognition came in September 1933, as we have seen, in which where she used the breadth of her work to highlight the 'considerably more responsibility' she had assumed since she first started as an accompanist in 1928. Arnold ended this appeal with an apology; both for having written at length but also for having asked for a rise at all. It 
had taken 'nearly a year to bring myself to ask for more money', she declared, 'as it is a thing I hate doing ${ }^{64}{ }^{64}$ This reticence is evident in the personal files of other BBC women, who rarely make a claim, even if there was awareness that their salary was lower than male colleagues. ${ }^{65}$ On this occasion, Arnold's voice was heard. Douglas Clarke, the Establishment Officer, conceded that her present salary was 'perhaps' low. ${ }^{66}$ Arthur Brown, the Variety Executive, was more robust. Both he and the Variety Director, Maschwitz, were of the opinion that she was certainly underpaid for the duties she performed. Her salary was the lowest of all the accompanists, Brown pointed out, while the $f 80$ rise in her pay over four years 'did not appear... to be commensurate with the rate of advance and the rate of the importance of her work'. Maschwitz was also adamant that, as a matter of urgent attention, Arnold's salary should not be less than that of Jean Melville, whose role was solely that of an accompanist. ${ }^{67}$ As a result of these interventions, Arnold was awarded a $f 60$ rise, taking her pay to $£ 400$, which was instituted in the April 1934 salary round.

Arnold, however, was not content with this increase which took her to the ceiling of her grade but no further. She made her dissatisfaction known to the BBC's Director General, John Reith. Reith epitomised the new generation of British bosses who embraced welfare measures as a way to promote loyalty and productivity amongst employees ${ }^{68}$ As part of this, he was prepared personally to meet with staff and in March 1934 Arnold requested an audience. In her letter, she explained that she had just been notified of her $f 60$ increase, which 'would be a very considerable rise in one year if I was still employed primarily as an accompanist' but, she stressed, this did not take into consideration how her work had become 'more and more creative' ${ }^{69}$ She wrote:

May I bring to your notice the fact that my position in the BBC, for the past three years has been a unique one, in that I am the only woman in the building who is doing creative work in addition to work as a pianist, for which I have been receiving a considerably lower salary than that paid to the other pianist in the Variety Department for work as a pianist alone. 
She told Reith that she had not troubled him before as she hoped that 'eventually the BBC would recognise the additional creative work I have been doing'. She could not help feeling 'rather discouraged' that 'even on April $1^{\text {st }}$ of this year I shall be receiving the same salary as has been paid for the pianistic work only for some long time.' In this, she was referring to Jean Melville. Although Arnold's pleading did not result in an extra increase, she was assured that the ceiling of her grade would be looked into at the next pay round. ${ }^{70}$ The following year, Arnold's salary increased to $£ 425$, bringing her above the level of Melville, and she was regraded ' $C$ '. ${ }^{71}$ However, it would take until April 1936, and a raft of special pleading, to finally bring her salary to $£ 500$ per annum, a level that satisfied both Arnold and the Variety Department. The negotiations that enabled this to happen tell a fascinating human story including health concerns, London living, and the vital issue of appropriate clothes.

In her September 1933 memorandum, Arnold argued that one reason why she needed to earn more money was the necessity to wear good clothes to work. Part of the preparation for her shows, she articulated, entailed visits to prospective artistes, which meant 'having to go to luxurious flats and places like the Savoy, where I must say, for the BBC's sake alone, apart from my own personal pride, I would wish to appear fairly well dressed'. The following year, her 'expense as regards to dress' was again used to support a request for a Benevolent Fund grant. ${ }^{72}$ By 1935 , Arnold's clothes had become the focus of wider managerial discussions. Concern was growing about her state of health and one of the reasons identified for her notable anxiety was the expense of dressing herself 'in accordance with [her] present position at the $\mathrm{BBC}^{\prime} .^{73}$ Gweneth Freeman, the Women's Staff Administrator, was asked to intervene, suggesting that Arnold's male colleagues and superiors considered this to be a woman's issue.

Unbeknownst to Arnold, two of her managers, Mungo Dewar of the Variety Department and Gerald Beadle, the Entertainment Executive, had approached Freeman, worried that Arnold was on the 
verge of a nervous breakdown caused by financial worry. ${ }^{74}$ At the subsequent meeting between Freeman and Arnold, she was asked to compile a breakdown of her expenses so that the extent of her difficulties could be assessed. At the top of the list was clothes. ${ }^{75}$ With BBC variety shows performed 'live' in front of an audience, Arnold was constantly in the public eye and while 'evening dress' for her male colleagues entailed a suit or dinner jacket, she was expected to look glamorous. As well as evening attire, Arnold informed Freeman, she also needed 'afternoon frocks for afternoon shows' as it was the custom for female performers to change outfits between sets. In addition, she also required 'suitable day frocks, suits, coats etc.' in which to meet with well-known artists as well as hats, shoes, gloves, handbags and so on. This would be 'humanly impossible', Arnold elucidated, but for the fact that she was able to make her own clothes. 'Having to do that', she proffered, 'is an extra strain because I can never really relax after I get home, as I always feel I should be sewing.'

Press stories about Doris Arnold confirm that she dressed well. Radio Pictorial in October 1935, for instance, depicted her as 'immaculate in pale blue suit, pale blue hat and pale blue fur'. ${ }^{76}$ Later editions of the magazine made explicit reference to her sewing skills. 'Dress designing' was listed as one of her 'whims' (as opposed to a skill) in October 1937 whilst the possibility that Arnold might hold the 'much debated title of the best-dressed girl in Broadcasting House' was seen as even more remarkable, in June 1936, because she made 'a great number of her own clothes'. ${ }^{77}$ Arnold's staff file also includes a number of requests for permission to be photographed in or to write about her clothes. This might be, for example, an article she wrote about 'Dress' for the 1934 Radio Annual, or photographs of her wearing furs, for general publicity purposes. ${ }^{78}$ Arnold's revelations about the cost of clothes in her account to Freeman casts light on an issue that specifically affected her as a woman - and a woman on an inadequate salary not only her for her status but also for the requirements of her job. ${ }^{79}$ 
Further expenses were detailed which included opticians, dentists and doctors' bills, at a time when private health care was the only option. ${ }^{80}$ Arnold's dental problems and health issues, including an emergency stay in hospital for appendicitis, had previously caused her to seek loans from the BBC. In this instance, she identified the need for glasses, caused by incessant sight-reading in artificial light, and she also emphasized the mental strain of continual broadcasting. 'If one is to do one's work well and with inspiration', she noted, it resulted in more frequent visits to the doctor. Her description of live studio work is palpable, 'the nervous energy expended and the inevitable reduction which follows when a broadcast is over, coupled with irregular hours, irregular meals, late nights, working in artificial light and ventilation.' This resulted in further expenditure such as the need for proprietary health tonics in order to cope with the amount to be done 'under the particular conditions which work at the BBC involves'. Tiredness meant she sometimes treated herself to the luxury of a taxi to and from her flat, again an expense not covered by the BBC (the flat was close by, in Marylebone High Street, and shared with a member of the BBC Wireless Singers, Rosalind Roswell). ${ }^{81}$ There was also the occasional cost of entertaining reporters from women's magazines, who requested interviews, and Arnold also admitted to purchasing 'odd things' for the flat, which she had recently moved in to. Her final confession was her embarrassment that:

in my present position at the BBC, or should I say, what many outside artists imagine is my present, very lucrative position, I am not able to return the many invitations I receive from numerous well-known people, but the expense of drinks and extra food make this quite impossible at the moment.

It is hard to imagine male colleagues revealing such intricate details about comparable troubles, even though the nature of their jobs at the BBC may have been similar to Arnold's. Indeed, the men around her were experiencing difficulties of their own. In November 1935, Dewar acknowledged the problem of overwork in the Variety Department as a whole and proposed, as a solution, that the 
department be reorganised. In his memorandum on the subject to Richard Howgill, the Director of Programme Planning, Dewar named 'Mr Maschwitz , Mr Watt, Mr Pepper and Doris Arnold', all of whom he believed were 'on the verge of a breakdown' ${ }^{82}$ The three men, however, did not have the additional worry of financial insecurity, nor the added pressure of being a woman on display.

Freeman was evidently extremely concerned about Arnold and, as extra ammunition to support her case for greater recompense, requested an even more thorough itemization of Arnold's expenses, over a three month period. ${ }^{83}$ The detail in this second list is again eye-opening and gives further insight into the living arrangements of a thirty year old, single woman sharing a flat in London. It also discloses more about her particular needs as a BBC employee. ${ }^{84}$ Alongside rent, gas and electricity, income tax and food, Arnold included telephone rental, which was vital for her contact work; piano hire, which was also crucial 'as I cannot do arrangements and practice in a busy office' and the cost of a radio-gram 'as it is essential that I listen to all types of programmes'. More generally, 'doctor's orders' required her to have a pint of milk a day and also Sanatogen, a health tonic which Arnold was supposed to take at least twice daily but, she stated, could only afford to take once. There was also a maid to pay '(two mornings a week only'), visits to the hairdresser and laundry costs, though the fact that she only had sheets and towels laundered suggests that Arnold hand-washed most of her clothes.

Arnold's budget was scrutinised by Freeman and her assistant Miss Redfern (who, it was noted, had wide experience of running flats in London). The conclusion reached was that 'in no instances would there appear to be extravagance; in some cases underestimating is apparent' ${ }^{85}$ Freeman then made a number of recommendations to Clarke, her senior in the administrative department. The first was that Arnold's salary should immediately be increased to an amount that would give her $f 10$ net each week. 'Not an excessive salary', she surmised 'for anyone of Miss Arnold's capabilities and position'. Arnold should also straight away be granted special leave of at least a fortnight as well as a 
Benevolent Fund grant to enable her to pay for a holiday. Freeman also advised that the BBC should contribute to the costs of the telephone, piano and radio-gram. In Freeman's opinion, unless something along these lines was quickly instituted, Arnold would have a serious breakdown.

Clarke in turn sent a response to his superior, Basil Nicolls, the Director of Internal Administration. ${ }^{86}$ Pointing out that Arnold's current salary ( $£ 425$ ) was 'greater than we would offer to many men to replace her', he also understood that she had 'particular utility and experience'. He agreed with Freeman that 'a woman has to incur considerably greater expenses in this job than a man' and accepted the findings that Arnold's hairdressing and clothes costs were in no way excessive. 'Judging by Miss Arnold's reports I would say that her work is definitely very useful' he determined, she had also 'built up a good deal of personal goodwill, which is worth a lot to us.' Clarke's view, however, appears to be that Arnold, whom he viewed predominantly as a female accompanist, was sufficiently well-paid. Nicolls was also evidently not prepared to give Arnold any immediate assistance as neither the health worries nor the financial predicaments were resolved at this time. Dibbs' observation of a 'culture clash' between the Variety Department and BBC administrators, who did not understand creative work, is apparent here. ${ }^{87}$ In January 1936, Dewar again championed Arnold's cause, articulating his concern that the 'colossal' workload and the steady pressure were severely affecting her health. ${ }^{88} \mathrm{He}$ outlined the drastic consequences of her having a complete collapse:

If she were to fall ill I can assure that it would require about three people to replace her, and the final result of the work by the three people would not be equal to Miss Arnold's. Her type of work is very far removed from ordinary accompanying, she is creating definitely in every piece of programme material she touches. 
Dewar reiterated Freeman's call for immediate special leave for Arnold at the BBC's expense and also re-introduced the consideration of a dress allowance because 'playing as she does before studio audiences I feel it is only right that we should do something to address her heavy expenses in this direction'. Dewar was so worried that he evidently approached Reith about the issue, who in turn raised these concerns with Nicolls. ${ }^{89}$ But, once again nothing was done.

Finally, in March 1936, the issue came to a head. The BBC's doctor gave the order that Arnold must take three week's leave. ${ }^{90}$ Whether this should be at Arnold's expense (she was about to receive her Ten Year Bonus) or the Corporation's then became the subject of emotive discussions between the most senior administrators in the BBC, including Charles Carpendale, by then Deputy Director General. Ultimately a grant from the Benevolent Fund was agreed. ${ }^{91}$ This realisation of Arnold's vulnerability, coupled with an excellent annual Confidential Report, appear to have at last prompted an acceptable pay rise. In his report, Maschwitz justified his request for a large salary increase by pointing out that, if the department had to pay outside arrangers and pianists for what Arnold did, there would be 'a very great expense'. ${ }^{92}$ He also emphasised her capabilities and that she should be regarded as 'a real expert in her own particular line - and paid accordingly'. Graves, the new Controller of Programmes, concurred and Arnold's salary was raised by $f 75$, to $f 500$ per annum. The following year saw a second sizable rise (a double increment) to $£ 580$ and a promotion to Grade B1. ${ }^{93}$ Again it was Graves who sanctioned this, adamant that Arnold should be placed in a position where the need for a dress allowance was no longer a concern.

Arnold's tortuous journey to a fair salary would have been a familiar narrative to other senior women within the interwar BBC such as Mary Somerville, Mary Hope Allen and Mary Chandler. ${ }^{94}$ In the case of studying Arnold's personal files, the financial cost of being a woman in the public eye adds an extra dimension. It is because she felt forced to justify her need for a higher salary that we, as researchers, are treated to such details about both her professional and personal life. Her status 
as a woman in man's world is also continually contested and exposed. The BBC's staff files can only

give a slice of an individual's existence, but in the case of Doris Arnold, we gain a strong sense of her character as well as the circumstances that dominated this period of her life. In terms of uncovering women's broadcasting history, it is revelations such as these that add to our overall understanding of what it was like to be part of the BBC in the early years of the institution.

\footnotetext{
${ }^{1}$ BBC Written Archives Centre (WAC), Caversham, L1/15/1 Doris Arnold, staff file: 1926-1951, Salaries Section to various BBC executives, 18 December 1935. All archival documents in this article are from BBC WAC.

${ }^{2}$ All BBC staff received a bonus on the completion of 10 years' service, which was assessed at $10 \%$ of their annual earnings.

${ }^{3}$ Radio Pictorial, 18 October 1935, 10 January 1936; 1 January 1937, 29 October 1937.

${ }^{4}$ David Hendy, 'Biography and the emotions as a missing 'narrative' in media history: a case study of Lance Sieveking and the early BBC', Media History 18, no. 3-4, (2009), 361-78.

${ }^{5}$ Alec Badenoch and Kristin Skoog. 'Lessons from Lilian: Is Transnational (Media) History a Gendered Issue?' Feminist Media Histories, 5, no.3 (2019) 9-35.

${ }^{6}$ Daily Despatch, 5 December 1934.

7 Fred Hunter, 'Hilda Matheson and the BBC 1926-1940' in This Working Day World: Women's Lives and Cultures in Britain Sybil Oldfield ed., (London: Taylor \& Francis, 1994) 169-74; Delia Jarrett-Macauley, The Life of Una Marson, 1905-65 (Manchester: Manchester University Press, 1998); Michael Carney, Stoker: The Biography of Hilda Matheson OBE, 1888-1940 (Llangynog: Michael Carney, 1999). Olive Shapley also published an autobiography about her life at the BBC: Olive Shapley, Broadcasting: A Life (London: Scarlet Press, 1996).

${ }^{8}$ Michael Bailey, 'The Angel in the Ether: Early Radio and the Construction of the Household' in Narrating Media History, ed. Michael Bailey (London: Routledge, 2009).

${ }_{9}^{9}$ Maggie Andrews, Domesticating the Airwaves: Broadcasting, Domesticity and Femininity (London: Continuum, 2012).

${ }^{10}$ Kate Murphy, Behind the Wireless: An Early History of Women at the BBC (London: Palgrave Macmillan, 2016).

${ }^{11}$ Virginia Marsden, 'Innovation, women's work and the documentary impulse: pioneering moments and stalled opportunities in public service broadcasting in Australia and Britain', Media International Australia 162, no.1 (2017), 19-31.

${ }^{12}$ Allan Jones. 'Mary Adams and the producer's role in early BBC science broadcasts', Public Understanding of Science 21, no.8 (2012), 968-83

13 Jeannine Baker, "Australian Women Working in British Broadcasting in the 1930s and 1940s", Feminist Media Histories, 5, no.3 2019) 140-67. Like Doris Arnold, Muriel Howlett started at the BBC as a stenographer. ${ }^{14}$ Jennifer Purcell. "Behind the blessed shelter of the microphone": managing celebrity and career on the early BBC - Muriel Constanduros, 1925-1957', Women's History Review 24, no.3 (2015), 372-88.

${ }^{15}$ Desert Island Discs is a long-running BBC series where famous individuals discuss their lives, through their record choice.

${ }^{16}$ Asa Briggs, The Golden Age of Wireless: The History of Broadcasting in the United Kingdom Vol. 2 (London: Oxford University Press, 1965), 89.

${ }^{17}$ Briggs, The Golden Age of Wireless, 94.

${ }^{18}$ Paddy Scannell and David Cardiff, A Social History of British Broadcasting, 1922-1939 (London: Blackwell, 1991).

${ }^{19}$ Martin Dibbs, Radio Fun and the BBC Variety Department, 1922-67: Comedy and Popular Music on Air (London: Palgrave Macmillan, 2019), 9, 10, 41, 48-9, 57, 116.

${ }^{20}$ There is no clear rationale about why the BBC retained some personal files and not others but it appears primarily to be inked to seniority and long service. Arnold has two files: File 1 contains the bulk of personal documents; file 2 is more concerned with sick leave and permissions to do non-BBC work. See also Rachel
} 
Mosely and Helen Wheatley, "Is Archiving a Feminist Issue? Historical Research and the Past, Present and Future of Television Studies", Cinema Journal, 47, no 3 (2008), 152-58.

${ }^{21}$ Arnold has an entry in the Oxford Dictionary of National Biography. Kate Murphy, Arnold, Doris Grace https://doi.org/10.1093/ref:odnb/105932.

${ }^{22}$ BBC Desert Island Discs, 25 September 1967, programme script.

${ }^{23}$ L1/15/1, Doris Arnold Staff file (in future, DASF1), Arnold to Nicolls, 26 October 1933. Most British children left elementary school at 14 . Tiffin Girls School was a fee paying grammar school, where exams could be taken at 16 and 18. Scholarships to poorer children in lieu of fees were offered, but it is not known whether Arnold was one of these.

${ }^{24}$ According to Desert Island Discs, Arnold won Silver Medal for" song accompaniment at sight" at the Wimbledon Music Festival.

${ }^{25}$ DASF1, Arnold to Nicolls, 26 October 1933.

${ }^{26} \mathrm{Ibid}$.

${ }^{27}$ Ibid.

${ }^{28}$ For more information on the role of the Women's Staff Administrator see Murphy, Behind the Wireless, 5358.

${ }^{29}$ There were 20 shillings in a pound.

${ }^{30}$ The average starting wage for female secretarial/clerical staff at the BBC was $£ 3$ a week.

${ }^{31}$ DASF1, Arnold to Nicolls, 26 October 1933.

${ }^{32}$ Radio Pictorial, 10 January 1936.

${ }^{33}$ Radio Pictorial, 29 October 1937. In the early days, the presenters of Children's Hour were known as Uncles and Aunts.

${ }^{34}$ Radio Pictorial, 25 June 1937.

${ }^{35}$ DASF1, Ralph Wade to Cecil Graves, Assistant Director of Programmes, 2 April 1928.

${ }^{36}$ For a wider discussion on the mobility of female staff at the BBC, see Murphy, Behind the Wireless, 74-79. A marriage bar was introduced into the BBC in 1932.

${ }^{37}$ DASF1, Farrar (of the Programmes Department) to Wade, 16 April 1928.

${ }^{38}$ For more on the conditions of service of salaried staff at the BBC, see Murphy, Behind the Wireless, 26-30.

${ }^{39}$ See Murphy, Behind the Wireless, 272. In 1939, Arnold was the eighth highest earning woman at the BBC.

${ }^{40}$ For a discussion on the BBC Variety Department in the interwar years see Scannell and Cardiff, $A$ Social History of British Broadcasting, 224-273. Also Martin Dibbs, Radio Fun, 13-105.

${ }^{41}$ Briggs, The Golden Age of Wireless, 89.

${ }^{42}$ Pepper already had a successful show business career when he joined the BBC, in particular as a pianist and composer. BBC WAC: L1/337: Harry S Pepper Staff File, August 1932.

${ }^{43}$ This has been compiled from searches on BBC Genome, a crowd sourcing site which contains listing information from Radio Times from 1923-2009. https://genome.ch.bbc.co.uk/.

${ }^{44}$ Apart from BBC broadcasts, Pepper and Arnold made numerous concert appearances and recorded many discs together.

${ }^{45}$ DASF1, Gielgud to Eckersley, 1 September 1930.

${ }^{46}$ The annual pay round at the BBC for established staff, (i.e. not performers or those on short contracts) took place in April each year.

${ }^{47}$ Hand-written note at the bottom of above document, dated 2 September 1930.

${ }^{48}$ Ibid., 8 September 1930.

${ }^{49}$ Dibbs, Radio Fun, 50. Martin Dibbs described the Variety Department as providing the 'bread and butter' of the BBC.

${ }^{50}$ DASF1, Announcement of new Variety Department, 31 March 1933.

${ }^{51}$ For example, Radio Pictorial, 18 October 1935, headed an article about Arnold, Watt and Pepper, 'The Gang'.

52 DASF1, Arnold to Clarke, 12 September 1933.

${ }^{53}$ This was a hugely popular radio programme, which included new and old West End show songs. It would run until the mid-1960s.

${ }^{54}$ DASF1, 17 July 1935, Dewar to Nicolls.

${ }^{55}$ Songs from the Shows was briefly called Songs from the Films.

${ }^{56}$ DASF1, Annual Confidential Report, 1936.

${ }^{57}$ DASF1, Annual Confidential Report, 1939.

${ }^{58}$ Radio Times, 19 October 1937. Arnold is credited as the presenter, alongside the soprano Margaret Eaves, the baritone John Duncan (both of the BBC Revue Chorus) and the Arthur Dulay Quartet. 
${ }^{59}$ DASF1, Annual Confidential Report, 1938.

${ }^{60}$ Radio Times, 26 November 1937.

${ }^{61}$ The Radio Times listing for 22 January 1939 included a photograph of Arnold at the piano, with the information that the 'new series of her popular gramophone programme of favourite melodies', was at 1.30 that afternoon.

${ }^{62}$ Arnold remained the programme's presenter until 1963, although for the final eleven years, she was on contract after having been 'let go' by the BBC. She and Harry Pepper married in 1943.

${ }^{63}$ For a wider discussion on women's reluctance to negotiate see Murphy, Behind the Wireless, 146-8

${ }^{64}$ DASF1, Arnold to Douglas Clarke, 12 September 1933.

${ }^{65}$ For example Isa Benzie, Olive Shapley and Alice Wright.

${ }^{66}$ DASF1, Clarke to Beadle, 30 October 1933.

${ }^{67}$ DASF1, Confidential Report, 1934.

${ }^{68}$ John Spedan Lewis, Director of the John Lewis partnership, is another example.

${ }^{69}$ DASF1, Arnold to Reith, 21 March 1934.

${ }^{70}$ The ceiling of Arnold's Grade, Grade D, was $₫ 400$.

${ }^{71}$ DASF1, Confidential Report, 1935 . Grade C salary range was $£ 400-f 600$. Melville remained on $£ 400$, the ceiling of Grade D. A number of male accompanists were earning $£ 450$ at this time.

${ }^{72}$ DASF1, Arnold to Wade, 3 July 1934. The Benevolent Fund was part of the BBC's welfare provision.

${ }^{73}$ DASF1, Arnold to Freeman, 10 July 1935.

${ }_{74}^{7}$ DASF1, Freeman to Clarke, 13 July 1935.

75 DASF1, Arnold to Freeman, 10 July 1935.

${ }^{76}$ Radio Pictorial, 18 October 1935.

${ }_{77}^{7}$ Radio Pictorial, 29 October 1937, 10 June 1936.

${ }_{78}^{78}$ DASF2, Clarke to Arnold, 21 February 1934; 11 April 1935.

${ }^{79}$ At this time Watt earned $\mathrm{f} 800$ and Pepper $\mathrm{f} 850$ per annum.

${ }^{80}$ The National Health Service was not introduced until 1948.

${ }^{81}$ DASF1, Clarke to Nicolls, 4 June 1935. Details about a request for a loan linked to the flat she shared.

${ }^{82}$ R13/311/2, Variety Department, Dewar to Howgill, 29 November 1935. See also Dibbs, Radio Fun, 55-60.

${ }^{83}$ DASF1, Arnold to Freeman, 10 July 1935.

${ }^{84}$ DASF1, Clarke to Nicolls, 4 June 1935.

${ }^{85}$ DASF1, Freeman to Clarke, 13 July 1935.

${ }^{86}$ DASF1, Clarke to Nicolls, 16 July 1935.

${ }^{87}$ Dibbs, Radio Fun, 55-60.

${ }^{88}$ DASF1, Dewar to Howgill, 13 January 1936.

${ }^{89}$ DASF1, Reith to Nicolls, 9 January 1936.

${ }^{90}$ DASF1, Clarke to Carpendale, 4 March 1936.

${ }^{91} \mathrm{Ibid}$. The discussions took the form of notes on the bottom of the memo.

${ }^{92}$ DASF1, Confidential Report, 1936.

${ }^{93}$ DASF1, Confidential Report, 1937. Grade B1 salary range was $£ 600-£ 800$ per annum.

${ }^{94}$ See Murphy Behind the Wireless, 147-49, 164. 